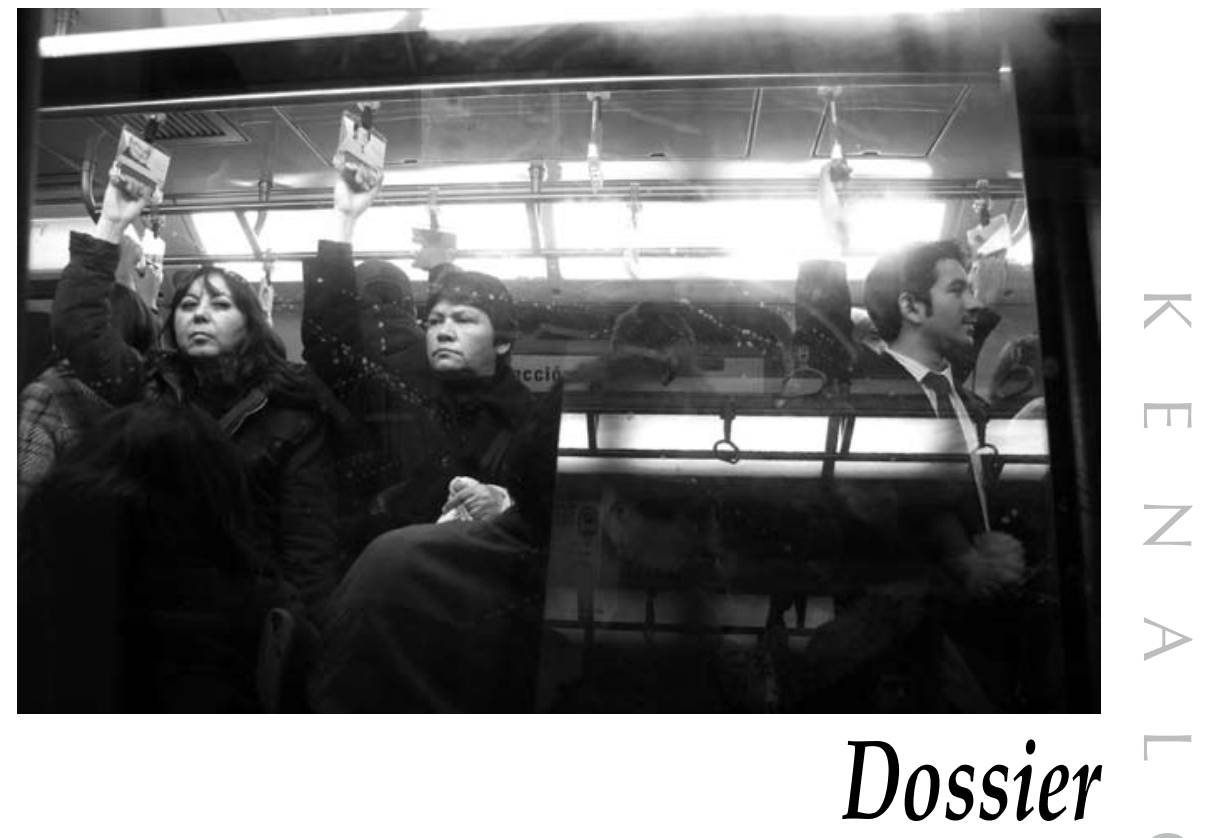

El aborto: zona de beligerancia en Chile

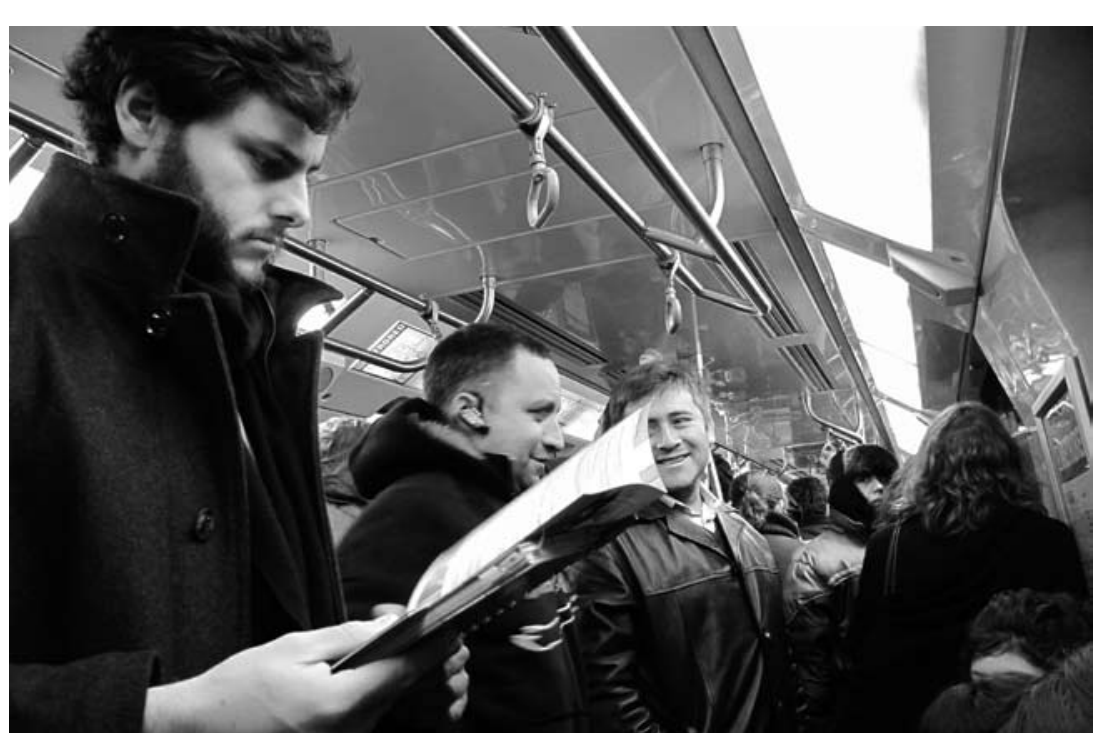

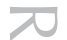

$\Pi \Pi$

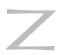

N 



\section{Voces entrecruzadas}

\section{Olga Grau ${ }^{1}$ y Soledad Falabella ${ }^{2}$}

Una de las experiencias que es propia de las mujeres, es la de vivir por más de tres décadas con la posibilidad de quedar embarazadas. En treinta años de fertilidad, se puede prever, sin duda alguna, que durante ese tiempo no podrán siempre desear tener un hijo o una hija. Asimismo, en ese lapso tan extenso, cualquier cálculo de probabilidades nos mostraría que la mayoría de las mujeres puede quedar embarazada sin proponérselo, incluso previniéndolo. Tener este hecho a la vista, hace que sean muy incomprensibles las políticas de restricción al derecho a decidir de las mujeres sobre su propia sexualidad, referidas al uso de métodos anticonceptivos - como el condón, en el caso de la Iglesia Católica, o la píldora de anticoncepción de emergencia- y a la posibilidad de abortar. En esas políticas, entre las que hay que destacar la penalización del aborto realizado bajo cualquier circunstancia, podemos reconocer los signos de violencia que aun tienen los sistemas sociales que dejan fuera a las mujeres en los diseños y propuestas de políticas públicas en un aspecto tan crucial de sus vidas.

Las mujeres fértiles en Chile no gozamos del derecho a acceder a ningún tipo de método para poner término a un embarazo. No tenemos derecho al aborto y con ello nuestro cuerpo pasa a constituirse en un bien común sobre el cual los otros, generalmente hombres, deciden. Esta situación no tiene ninguna equivalencia para los hombres. En este sentido, la ilegitimidad del aborto en Chile se instala como una evidente discriminación en contra de las mujeres. Superar esta barrera dependerá de los recursos económicos de cada mujer, instaurando un segundo nivel de discriminación. ¿Cuáles son los dispositivos discursivos capaces de abordar la problemática del aborto en Chile y del derecho de las mujeres a decidir sobre su propio cuerpo? ¿De qué modos se puede transitar por un terreno tan controversial, lleno de trampas y equívocos? 
La ilegitimidad del aborto tiñe la esfera pública chilena, espacio donde por excelencia debiéramos debatir sobre los asuntos de la ciudadanía. Esto no solo empobrece la calidad de nuestra democracia, sino que configura una zona discursiva de abyección y de prácticas de silenciamiento. Para la promoción de una ciudadanía sexual digna y plena es fundamental subvertir la carga negativa del aborto y movilizar los imaginarios en torno a este tema tanto a nivel subjetivo, social, cultural, político como ético. El presente dossier busca contribuir al debate en torno al aborto de una manera consciente de las dificultades de enfrontar un tema complejo en sí mismo y que además cuenta con la carga de estigmatización social. Hablar sobre y desde lo ilegítimo nos abre a cuestionar la institucionalidad misma del dispositivo discursivo; por ello hemos optado por la estrategia del montaje, privilegiando la figura de la yuxtaposición de una pluralidad de registros: narraciones de vivencias, testimonios poéticos y opiniones de actores sociales que trabajan relacionados con el tema.

Con este frote de textos esperamos aportar a la reflexión y discusión entre mujeres, e incentivar el debate sobre el aborto que no pierde actualidad, apareciendo en las disputas la reiteración majadera de argumentos que muestran su enorme precariedad enfrentados a la realidad y que exponen su tremenda violencia en la supresión de las voces de las sujetos más comprometidas en las experiencias de embarazos no planificados y embarazos no deseados. Aquí, damos lugar a algunas de esas voces anónimas; nombres tachados para cautelar la libertad de quienes nos las han donado.

\section{Notas}

1 Académica de la Facultad de Filosofía y Humanidades de la Universidad de Chile.

2 Directora de ESE:O (Plataforma virtual de textos académicos). 